\title{
Applying the Values and Practical Implementation of Agricultural Science in Nigeria farming System
}

\author{
Osondu Chimezie Nworu \\ Osondu \& Associates Design Architects, Nigeria
}

\begin{abstract}
No one can underrate the many significant contributions and potentials for Agriculture in the totality of the Nigerian economy. The key to developing agriculture in Nigeria is studying, researching and identify means to efficiently support the small-scale farming practiced by a majority of the populace. The paper is not advocating the abandonment of the medium and large-scale farming levels, but the small and scattered agriculture prevalently practiced has evinced the needs to empower more this category through receiving more support from aid donors and the governments. Therefore, identifying ways to encourage this level of farming is vital, though presently middle and large-scale agriculture is receiving more emphasis, which does not correspond to any visible increase of the gross national products. Also, for the fact that the above 75 percent of the population that engages in agriculture that gets up to about 95 in some urban and rural areas during the rainy season are mostly small-scale farmers. These, are the lots of the small farmers that cultivate about $90 \%$ of the 83 million hectares developed of the 98 million hectares of the arable land area. As per Nigeria, small-scale farming accounts for about $\mathbf{9 5 \%}$ of total agricultural output - Federal Ministry of Agriculture, 2005 [1]. For the fact that agrarian science is such a broad multidisciplinary field, the goal to pursue is self-sufficiency in food production to enhance the lives of the masses by improving the capacity of the small-scale farmers who efficiently produce almost the food consumed through the innovative applications of some parts of the discipline of agricultural science. Notably, by applying Soil Science, and Production techniques like irrigation management, recommended nitrogen inputs, thereby improving the agricultural productivity, optimally dissemination of information and free urban/rural farming vocation skills pieces of training. Also, shall invariably enhance productivity and remove from the farmers the stress of always relying on seasonal rainfall and from the catastrophe to the ecosystem caused by the bush fallow system, especially in the Niger Delta region because of the high rate of gas flaring. Mainly this time that the UNEP in Ogoniland (topsoil) cleanup operations that are going on to improve the environment and grow healthier efficient crops for consumption.
\end{abstract}

Keywords: Farming, Production, Cultivation, Economy, Development, Agriculture, People, Environment,

\section{INTRODUCTION}

One of the most significant differences between European and any African countries is not on edifices as is easily presumable but on the abundance of empty arable lands. If one should travel by train from Rome to Frankfurt, one will notice a nonstop continuation of cultivated lands of various crops and forages for livestock from the beginning of the journey to the end. While if one should do the same distance from Lagos to Accra in Ghana for example or even within Ghana or Nigeria from Port Harcourt to Lagos, the one will be surprised that the cultivated lands among tick bushes countable will be in tens. The FAO defined arable land as land under temporary crops, temporary meadows for mowing or pasture, land under market or kitchen gardens, and land temporarily fallow. However, farms abandoned because of shifting cultivations are not among the arable land. Nigeria had in1990, 91million hectares of the overall land expanse of which 82 million hectares were cultivable and of the arable, only $42 \%$ was cultivated. 
By 2014, according to a World Bank report, the cultivable percentage of the land area had reduced to $37.33 \%$. It is empirical that every sector of the national economy has been tending to weaken, including agriculture since the 1960 s, which means that only about $11 \%$ of the total national arable land area has cultivation. Even though presently, in Nigeria "Farming has become a vocation for people with nothing else to do," [2]. Apparently, in Nigeria, there is a practice of leaving lands idle for an extended period to allow natural regeneration of the soil fertility. This practice does not justify the vast amount of uncultivable lands unused in the country. This phenomenon represents a significant challenge to the government and the agricultural policymakers to address. For this is one of the leading reason, the nation is not self-sufficient in food production as it was in the 1960s, when every arable land was farm because $99 \%$ of the population were farmers. Still, seeing the rapid population growth and the youth unemployment rate if the government can direct at least $70 \%$ of the declared unemployed youths to farm with enticing incentives and technical supports Nigeria shall become once again a significant exporter of food products. With the vast hectares of land that is available in the country even still depending on the traditional mode of farming and seasonal rainfall; increasing the number of farmers by $70 \%$ will raise the actual farmlands from $30 \%$ of the cultivated arable land area to above $40 \%$ to achieve self- sufficiency in food production. All that is required is to make sure through sound government policies that farmlands sprout up like mushrooms in the bush or markets in urban Nigeria to enjoy self-sufficiency in food production once more as in the 1960s.

Another challenge to farming in Nigeria is that of flooding; evidently, the Sea level rose $20 \mathrm{~cm}$ in the last century as the result of climate change that is aggravating flooding causing physical danger all over the world. Empirically, Nigerian farming depends on seasonal rainfall the flooding could be a blessing in disguise if the nation creates a way of utilizing the excess water or rains. Up to date in Nigeria, it is typical conveying the flooding by digging gutters of about 9 inches thick to redirect the flood back to the same overflowing river. Nigeria has pluvial flooding as such the local, state and federal governments can construct a series of connecting canals within the cultivable lands that end up in some reservoirs connected to each other also, to form a useful tool for irrigation during the dry seasons.

Apart from the beneficial use of the excess water for irrigation and fish-farming activities, recycling the water will save towns, village and lives avoiding the recurrence of the lost lives and property of the worst floods in recent year. Six years ago in March 2012, severe floods affected thirty-two of Nigeria's 36 states. That killed more than 360 people, and almost 2 million people were displaced [3].

The problem of flooding is worldwide and expected to reoccur yearly in Nigeria; as such, the federal ministry of agriculture should review its water-resource management policy to reduce the yearly number of fatalities. By taking practical measures of creating an ad hock body to take control of all the nation's river's banks, besides giving adequate maintenance to the existing water reservoirs and dams. Also, set technically innovative sound projects to use the excess water that currently devastates across the nation to enhance farm productivity and even help to farm twice a year in the country.

\section{Objective of Paper}

The aim of this paper prepared for the Plant Science and Physiology 2018 International Conference in Osaka of May 21-22, 2018, is to use the medium for highlighting potential improvement of the existing system of agriculture in Nigeria through the implementation of the values of agricultural science. 
By focusing, on the two primary factors, the land, and the farmers the paper shall underscore the challenges that are limiting productivities and give essential suggestions to the achieving sustainable economic growth of all potential agricultural sectors. The article shall focus on using the existing traditional farming systems as the underpinning to enhance developing strategies beneficial to agriculture in the country.

\section{Subsistence Agriculture}

\section{THE VARIOUS INDIGENOUS FARMING SYSTEMS IN NIGERIA}

Subsistence farming is typical of Nigerian because of the importance of the family in the society as the primary intention of every family is to provide for its basic needs from the farm and whatever remains of the farm's products is destined to market for other needs. Families have lived in this way in Nigeria and entire Africa from time immemorial; and to increase farm produce for marketing purposes brought about polygamy into the family system, as there was a need for more children to farm more lands. The essence to increase productivity and the high proliferating commercialization of farmlands is the reason behind vicious land disputes and on a larger scale territorial dispute in the country. Nigeria exports gazillions of cash crops including palm kernel oil, gum Arabic, groundnut, palm oil, sorghum, sesame, Soya.

Others are beans, cassava, plantains, rice, yams, maize, cashew nuts, millet, melon, bananas, rubber, vegetables, and fruits, exports mainly to Western Europe, Canada, and the USA. However, the staple food crops are yams, corn, cassava, rice, and beans among others.

Since the era of the oil boom in the 1970s, the Nigerian agricultural economic sector has lost the capacity of producing sufficient food for the nation and the top position it once occupied as a significant producer and exporter of palm oil, cocoa, groundnut, and rubber. Nonetheless, the crops productions are by any of the following three methods of subsistence agriculture namely,

(a) Intensive subsistence: - traditional farming system,

(b) Shifting cultivation: - bush fallowing which entails leaving land uncultivated for few years after planting.

(c) Pastoral nomadism: - traveling around communities or the nation with herds of animals looking for good pastures for the animals to graze. A considerable percentage of the Nigerian farmers are also engaged in fishing, raising livestock, poultry, snails rearing and piggery.

\section{The Traditional Farming and Shifting Cultivation Practice}

The goal of the paper at this moment is to highlight the primary agricultural systems practiced in Nigeria to arrive at promoting the farming practice that can enable enhancement of knowledge and technical farming novelties among the people. Mainly, now that many people are venturing into agriculture because of its economic benefits in the face of current scarcity of foodstuff in the country. It is essential to encourage the masses to practice farming and produce for themselves, for in the present economic situation in Nigeria anyone who cannot farm to sustenance at least the family is lost. As alluded above, shifting cultivation is quite rampant in the Southeastern Nigeria that invariably is bush fallowing, digging ridges or making heaps of mounds to plant and application of fertilizer to the crops and weeding with local tools. Southeastern Nigeria has a very high density, and polygamy is widespread which means that every patch of land diminishes in size every time there is the land division because of inheritance. The inheritance phenomenon influence significantly the quantity of the overall yearly harvest, which, continues to decrease as the farm, gets smaller because of the recurring inherited land slit up among family members. Therefore, renders the small-scale farmers perpetual small and limiting their potential productivities to small essential subsistence production only. This factor influences very much negatively on the locals' income and 
indigenous farming skills, therefore, frustrating the ability of every individual farmer's capability to expand and grow. Thus rendering none possible mechanizing small-scaled farming and economically viable, especially in the Niger Delta while mechanizing farms can be likely and financially feasible in the Southwest and entire North of Nigeria because of extensive vast hectares of land due to less density of the population.

Although, agricultural practice in northern Nigeria is usually a combination of livestock rearing and farming by the peasants, which contrasts to the South of Nigeria, where livestock rearing is not rife.

The principal crops here are sorghum, wheat, sesame, cowpea, millet, and groundnut including onion, garlic and rice garbage, tomatoes, melon, and cucumber from the sandy soil

In this area, the farmers have extraordinary knowledge of the earth and the ways of protecting the soil nutrients including possessing an outstanding ability to manage the animal wastes they integrate into the soil. As during the day, the animals graze in the fields to leave the excrement while they stay in the pens during the night. The management is such to avoid wasting anything from the ground including weeds, vegetation or crops abandoned in the field are to feed the animals

Northern farmers practice dry-season cultivation also, during the dry season there is usually well marked rainy in the area, and the rainfall is very intensive whenever it falls. Hence, the farmers are astute for practicing soil moisture conservations techniques to allow crops generate more nutrients because of a severe dry season. These are carryout out with the help of some shrubs and trees in the riggings to conserve water for vegetations.

\section{Nomadic pastoralists-Fulani Herdsmen}

Fulani is one of the ethnic groups in the north of Nigeria; the tribe has rich historical background after many decades of jihads in the late nineteenth century it became a ruling class in the north of the country, and however, the Fulani tribe has ever since remained good farmers. In Nigeria, a considerable number of the tribe known as Fulani pastoralists have stayed faithful to pastoral life spending almost their lifespan in the bush with their livestock. Fulanis are mainly from the semi-arid West Africa and the Sahel, a region of about 5,400 km that cut across some nations. Like Senegal, southern Mauritania and Mali, central Mali, northern Burkina Faso, central Chad central and south Sudan, South Sudan far north, Eretria, Cameroon even after the Congo Democratic Republic. In fact, the region extends from the Atlantic Ocean in the west to the Red Sea in the east. Fulani herdsmen whose primary occupation is raising livestock are either nomadic or semi-nomadic. They migrate with the cattle wandering at random in contrary to the semi-nomadic herdsmen that at the end of every migration do return to their base.

In Nigeria, the common livestock of the Fulani herdsmen is sheep, goats, cattle, donkeys, camels, and horses, which are the primary sources of $90 \%$ of meat consumption in the country. The reason of nomadic pastoralism is searching for fresh pasture and water because of the semi-arid climate of the region however frequently, their movements with the herds traditionally always is out of arable lands as pasturable lands are easily identifiable among the empty bushes. Arable land is from Latin arabilis meaning plowable or land suitable for cultivating. Moreover, when the mainstay of the economy of a people is agriculture, the love for nature or law of nature supersedes any human law, and in the case of violating the environment, the consequences are terrible affrays that are avoidable. 
Huge crowds turned out in central Nigeria on Thursday at a funeral service for scores of people killed during clashes between cattle herders and farmers [4]. As such, destroying farmer's lives and cultivations is an abomination that is the reason the government should not display nonchalant attitude but address the issue. The herdsmen's killing of farmers and destroying crops will only escalate possession of arms in the country for defense against the herders who may not be Nigerians. As it stands, no state in Nigeria has not experience Fulani herdsmen killing its farmer and farms destruction. It has been since the end of Nigerian civil war in 1970 that the Fulani herders had been traveling from one part of the country to the other peacefully without clashing with communities until 2010. The herdsmen now move in large groups, and heavily armed are ever ready to dispute and engage any innocent communities with machine guns. Besides, according to Global Terrorism Index 2015, the Fulani militant group operating in Nigeria and parts of the Central African Republic are the fourth deadliest known terrorist group in the world in after Boko Haram, ISIS and Al-Shabaab [5].

\section{Fish Production in Nigeria}

Local fish and shellfish are excellent. One can buy croaker, mullet, red snapper, sole, and barracuda beautifully fresh fish at six in the morning when the boats come in on Bar Beach Lagos. Jumbo shrimps, caught locally and frozen, are a real delicacy. Besides, it is possible to buy crabs, lobster, and oysters although you must make sure they do not come from polluted inshore waters [6]. The fact is that Nigeria is full of rivers, lakes, fresh and salt waters and has a coastline of $853 \mathrm{~km}$ [7], besides all their great products. The seas are enough to satisfy the domestic demand for fish/seafood and for export, as it was the case up to a few decades ago when the inhabitants of Niger Delta and around Lake Chad only were satisfying the domestic fish demands while fishing companies in Lagos and Port Harcourt did the exporting. Most of the indigenous and foreign fishing companies folded up in the 1980s because of series of federal military governments' unfavorable policies especially monetary, as they could not cope with the black market rate of foreign currencies to run their companies or to remit the dividends. The two primary sources of fish producing, the inland waters artisanal and the industrial fishing have suffered series of irreparable setback over the past years. Fishing as a livelihood that was providing for almost the entire nation is lost forever to Oil operations, spills, and leaks. Devastated Ogoniland by Shell and other oil companies in the area; a 1,000km kingdom in the Niger Delta, and the livelihoods of the Ogoni people who were predominantly farmers and fisher people [8].

The surface area of Lake Chad has shrunk from 25,000 square kilometers in the 1960s to 4,800 square kilometers in 2014. According to the United Nations Environment Program [9] worst still, the population around the lake has more than doubled from 17million in 2005 to present almost 38 million.

The industrial fishing Subsector is moribund, and the industrial fishing Subsector lost revitalization and development when the General Buhari military government refused to continue on the river basin authorities and Green Revolution Programs. There is now the need for promoting and organizing new angler cooperative societies. The need arises because anglers constrained by lack of funds cannot afford in the present economic situation to buy the pieces of equipment needed for fishing. They cannot secure boats, nets and outboard engines that are beyond their means. There is also lack of capital for processing facilities for preserving fish, transport facilities for product evacuation and establishment of a marketing network [10]. The only hope for the masses, lies on foreign investors and aiders seen the investment attractiveness in favor of employment, revenue, foreign exchange, and export base growth. Also, for the development of potentially sustainable aquaculture fisheries, that is struggling because of a lousy national economy and the governments' inertia. While the locals around the 
riparian areas can feasibly handle the extensive aquaculture, but where more agricultural science values need implementing are in the intensive aquaculture be it in the field of facility erecting and the breeding itself. However, many but not enough Nigerians engage in smallscale home fish growing using every sort of enclosure, ponds, and tanks. The dominant tilapia fish and catfish production level is still far from satisfying the national demand, as the current productivity cannot cover up more than $16 \%$ of entire nation's fish supply.

There is a vast market in Nigeria for the aquaculture Subsector because of the scarcity of meat and the population figure, which, however, requires considerable capital investment, and agricultural science values implementations, especially as regards to breeding fish fingernails, reducing fish mortality rate, water $\mathrm{PH}$, and manufacturing fish feed. These primary issues impair fish production and militate against the sustainable development of fish farming in the country. If the fish farmers can receive enough help in these their Achilles heel and in breeding more species of fish, fish farming would significantly contribute to diversifying the nation's non-oil economy.

\section{Poultry Farming}

In Nigeria, poultry farming is profitable, and poultry products are in very high demand because of population growth and the high price of agriculture foodstuff.

To satisfy present population, Nigeria needs to increase the current numbers of poultry farms in the country by 100times to get to European poultry eggs and meat supply standard. For this reason, poultry farming in Nigeria still needs a long way to go concerning investments and in meeting up with the enormous market demands for poultry eggs and meat. Apart from the commercial attractiveness, Nigeria has perfect tropical climate and environment to thrive poultry farms including free range. With a little capital investment and practical technical knowledge in poultry farming, any company worldwide would make a fortune in Nigeria, poultry products as per some decades to come to the demand shall become a challenge to surmount, seen the population growth and the invisible hand in Nigerian free market economy.

\section{Heliciculture or Snail Rearing}

This sub-sector of agricultural covers the study and farming of snail hence the business of rearing land snails for consumption or meat escargot, snail slime used in cosmetic and snail eggs for consumption as any other egg like chicken. In Nigeria, people usually go into the bush to pick snails in the night after rainfalls or when the forest is humid. Nevertheless, as the quantities and qualities of snails picked from the bush cannot naturally be economically viable many Nigerians have resolved to farm snails, and the business is resulting lucrative especially the African giant land snails. The most popular snail in Nigeria is the achatina achatina species. Achates from the Greek agates (a volcanic rock) hence achatina being the largest of the three African giant snails the other two are achatina marginata and achatina fulica. The achatina fulica species considered evasive as they can in freedom, affect agriculture and ecosystems adversely; even in some Caribbean nations, they farmers use them as pests. However, in Nigeria, practicing responsible farm management, snail farming remains environmentally friendly as their wastes do not pollute the environment and the farming site can be anywhere in the bush, in residential areas, outskirt, inside or outside the house as far as it is somewhere convenient and conducive to heliciculture.

\section{Dairy and Piggery Farming}

Piggery farming in Nigeria agriculture sector has a tremendous economic potential to grow the sector for export and at the same time satisfy the domestic red meat demands. One of the 
attractiveness of the Subsector is that it has every potential to expand and grow quick revenue due to the rapidly increasing nature of pigs and lack of meat in the country that can determine quick return of investments in a short period. After petroleum, the Nigerian economy is strongly dependent on agriculture and because the society cannot live without aliments which make investing in agricultural farming like piggery important and profitable business.

An area in which the values of Agricultural science can be useful is in the case of significant investments in a mixture of both animal husbandry for milk and piggery farming. As the nation is lacking dairy companies that are efficiently producing milk and dairy products that are in short supply in the country. The government and international aid organizations should support and promote breeding cattle for milk even more in the face of Fulani angler's menaces all over the country. Also, breeding animals for milk to processed for commercial purposes and using the waste for piggery farming is a type of long-term friendly environmental investments or projects the governments, wealthy Nigerian individuals, and foreign investors should participate in this highly profitable farming and better the lives of the citizens. There are the top cattle breeds that produce most milk, which are the world's top production dairy farm animals [11]. The implementation of agricultural science is vital in choosing the breeds, as there are more than 800 cattle breeds that produce milk for not all animals kinds are suitable for milk production.

\section{Forestry in Nigeria}

Forestry among others is a sub-sector of Nigerian agriculture, and it embraces around $10 \%$ of the national land area. Forestry land area is steadily decreasing because of corruption and environmental mismanagement that is the consequence of lack of environmental consciousness moreover, an unfortunate complete absence of sustainable environment thinking that is rife. Forest Management now abandoned entirely in the hands of some unscrupulous locals and foreigners, as the forest management planning does not exist; like block area control, felling cycles and allowable cuts have been discarded [12].

Nigeria agricultural industries both the formal and informal subsectors dominantly controlled by the private sector whose aim is only to make money compounded by the pressure of the present economic adversity unusually severe high rate of unemployment and underemployment that has driven the masses into the forest exploitation. The unscrupulous foreigners are notably Chinese, Lebanese, and Indians are furiously scrambling for rare hardwoods from every locality in the country even the remotest part. They are going to inevitably, deforest Nigeria in the next 5years. The unprecedented surge in illegal logging of hardwood for the booming of Chinese luxury furniture market is going to absolutely, exhaust the formal forest sector of log or wood-based industries including sawmills, chipboard, and plywood manufactures. Apart from the natural desertification, of northern Nigeria savanna forest reserve another environmental crime to the nation's forestry is in the informal subsector that is the everyday wood-based sector. In this sector, there is a real disaster is happening because of a large number of the population that depend on wood and non-wood forest products for domestic consumption.

Nigeria's forest cover is fast reducing at 3.5\% annually, says the Minister of Environment, as many states were witnessing unprecedented high rate of deforestation and forest degradation arising from intensive logging of timber for the export market and fuelwood extraction for domestic energy purposes [13]. Moreover, the most disheartening is occurring in Nigeria's Cross River State as the state Chairman of Forestry Commission told CNN: "The rate of deforestation in Nigeria is quite frightening. What is left is less than ten percent of the whole country, and more than 50 percent of that is in Cross River State [14]. In Nigeria, the states 
control forest reserves as such Governor Benedict B. Ayade who is a winner of a desertification award, and once a member of the Senate committee on environment and ecology cannot pretend not to know the irreparable consequences of deforestation going on in his state's forest reserve. The paper pleads the prompt intervention of his Excellency to stop the terrible destruction of the forest reserve for the sake of posterity the indigenous who are expecting sustainable development and good governance from him. Moreover, it will be nice if he can expel the Chinese from the rainforests in Cross River State and use them to make a unique contribution to the Queens Commonwealth canopy.

\section{THE DETERRENTS TO NIGERIAN AGRICULTURAL PRODUCTION AND ECONOMIC GROWTH}

The challenges agriculture is encountering in Nigeria are due to lack of government assistance to the small-scale farmers who in reality produce the foodstuff consumed in the country. The government has always relegated the farmers to peasantry lives and drudgery thereby rendering the total output of the small-scale farming insignificant. Those are the reason discouraging the youths to take to a life of farmers because it does not look attractive to investments. There is nothing wrong with the small-scale traditional farming methods only that the government has to appreciate the struggling farmers and grant them generous incentives and aids.

The fact is that more than $70 \%$ of the Nigerian population is mostly engaged in agriculture, which requires subsidies, loans, and credit from the governments. The funds could be accessible to the locals through rural microfinance banks to boost food production, the economy of the rural agricultural sector and to empower the poor and the marginalized peasants.

Besides, using this means to combat the high rate of rural unemployment in the country, paradoxically who can remember that in the 1960 s about $90 \%$ of the population were engaged in agriculture, yet the families were doing everything possible to enlarge in numbers for more labor force in agriculture.

Some past governments took positive steps in their quests to address the issue of the nation's inability to achieve food self-sufficiency and reduce excessive importation of food items. One of which was to create in 1972 the Bank of Agriculture Limited to enhance agricultural production in the country and to let monetary transactions thrive in the rural areas.

The goal of setting up the bank was, among others, to make provision for credits to support every activity in the Agricultural Value Chain. Also, provide for non-agricultural microcredit to the weaker segment of the society comprising rural artisans, petty traders, and a boost of opportunities for self-employment in the rural areas to stem rural-urban migration [15].

Probably inspired by the 1964 River Niger Commission in 1976 the federal military government established 11 Nigerian River Basin Development Authorities (RBDAs) to supply water for irrigation and domestic water supply, improve navigation, hydroelectric power generation, recreation facilities and fisheries projects. The basins were also supposed to engender big plantation farming and encourage the establishment of industrial complexes that could bring the private and public sectors in joint business partnership [16]. Concurrently, in 1976 there was also the Operation Feed the Nation a failed scheme that mainly was characterized by the official's money squandering and sending unprepared undergraduate into rural areas to teach more experienced farmers farming categorically. 
The brilliant initiatives of the past regimes failed to impact on the people because of the empiric Nigerian corruption, followed by lack of transparency and accountability. Furthermore, the bank could not discharge its main objectives because its fundament was the embodiment of nepotism, tribalism, and unpatriotic of all manners including its employment policy. The liquidation of the RBDAs later occurred because of the insouciant management of the people's affairs by the military regime that deposed President Shagari from office. Then in 1980, the President Shagari administration had instituted the Green revolution program (GR) to improve the previous governments Operation Feed the Nation (OFN) that was to restore in Nigeria by 1985 food self-sufficiency through the application agricultural science in the national agricultural economic sector and boost mostly the production of rice and fish. The program was to prosper through the implementation of various innovative technologies like fertilizer, high yielding variety seeds (HYV) and use of different types of farm machinery in all the 11 river basin development authorities. Besides, the program remarkably had various agricultural centers that had specific specialization namely the Umudike Cassava Centre, the Ibadan Rice/Maize Centre and the (AERLS) Sorghum/Millet/Wheat, the Ministry of Water Resource. It could have been the most brilliant and resourceful project ever realized by any administration to strategize and efficiently enhance food and fish production in Nigeria.

By 1980, the implementation of government program had already begun in full swing beside, an initial short-term budget of N18.3 millions to procure 200 tractors for hire. Cleared every empty arable land, and provided fishing trawlers to the fishermen cooperatives also bought 500 tonnes of improved rice and maize varieties and inputs, 500,000 tonnes of fertilizers, drugs, and vaccines to combat animal diseases all procured items distributed across the 19 states. Unfortunately, the miracles scheme that was to yield in 1985 suffered a premature death in 1983 when a military intervention usurped Shagari's authority [10]. One of the primary reasons European countries develop easily develop more than Nigeria or any other African nation is the Europeans respect the principle of continuity. In the sense that, from the local governments up to the federal governments, every European government always continue and finish up or ameliorate any unfinished project or program of the previous governments which African countries do not practice. In Africa, every tier of governments that comes in usually condemns, ignore, discard, reject or most of the time destroy the predecessor's scheme. A good example is that of Mr. Okorocha who when he became governor of Imo state in 2011 discarded and destroyed all projects of the previous governments worth billions of naira to execute a new program. The same happened in 1983 when more than two hundred billion naira in today's exchange rate as Buhari's government abandoned the Shagari's green revolution to introduce the Go Back (School) to Land program [17].

Since 1983 that the federal government laid off all the basins authority workers the rate of unemployment in the country has been rocketing. The rivers are now discarding ground of industrial oil, grease and household wastes polluting the aquatic ecosystem of the entire nation and the water quality of streams, environment, and ecosystem, especially Niger Delta devastated by a constant oil spill of the various oil companies.

\section{CONCLUSION/RECOMMENDATION}

The paper has underscored the primary agricultural practices in Nigeria including piggery, fishing, livestock, poultry, snail, forestry, and highlighted the various crops produced including palm kernel oil, groundnut, palm oil, sorghum, sesame, Soya, beans, cassava, plantains, rice, yams. The paper has also highlighted the significant challenges facing the development and the progress of farming in the country and as to how the application of the values of agricultural science in the farming system can become a benefit. The blessing of the nation with every type 
of resources including human resources to perform a green revolution miracle especially with the vast arable land areas and an abundant water resources in the country.

The paper also recognizes the need to develop the country's economy through non-oil exporting products with agricultural goods to diversify the economy, create employment opportunities for the government to achieve standard revenue to relieve the current substantial portion of the population $70 \%$ from wallowing below the poverty level. However, the development of any potential economic sector in the nation including agriculture and all its subsectors must be altogether two-ways qualitative and quantitative growth, however not qualitative for few as usual, but there should be an increase in quality of life for all Nigerians, which are sustainable. The government and the people of Nigeria have to be conscious that every single develop must follow strictly sustainable development: "that meets the needs of the present without compromising the ability of future generations to meet their own needs". [18]. Mainly, in agriculture forestry subsector where desertification and clearing for legal and non-logging timber for export have no parallel in the destruction of the heritage. How unwise is it to be clearing thousands of years mix forest reserves of the nation to replant them with one species of a particular tree plantation that only amounts to an adverse environmental sustainability forest management.

\section{•'... To God Be the Glory}

\section{Reference}

CTA, (2008). Assessment of Agricultural Information Needs for Cta's Products And Services in African, Caribbean \& Pacific (Acp) States - Country Study: Nigeria. CTA. Available at:

https://cgspace.cgiar.org/bitstream/handle/10568/52378/Final_report_Nigeria.pdf?sequence=1

The Economist (2013).Farming in Nigeria: Feed yourself. The Economist. Available at:

https://www.economist.com/news/middle-east-and-africa/21577113-if-only-nigeria-could-revamp-its-farmsfeed-yourself

BST (2017).Why flooding in Nigeria is an increasingly serious problem. THECONVERSATION. Available at:https://theconversation.com/why-flooding-in-nigeria-is-an-increasingly-serious-problem-82272

The Guardian, (2018). Benue: Mass burial for farmers murdered by Fulani herdsmen. odili.net. Available at: http://odili.net/news/source/2018/jan/11/6.html

Buchanan R. T., (2015).Global Terrorism Index: Nigerian Fulani militants named as fourth deadliest terror group in world. INDEPENDENT. Available at: http://www.independent.co.uk/news/world/africa/global-terrorismindex-nigerian-fulani-militants-named-as-fourth-deadliest-terror-group-in-world-a6739851.html

Cox E., \& Anderssen E., (1984). Survive Lagos. Spectrum Books Ltd/Safari Books (Export) Ltd ISBN094648005-2

CIA world-factbook, (2017).FIELD LISTING COASTLINE the-world-factbook. Available at: https://www.cia.gov/library/publications/the-world-factbook/fields/2060.html

Keates E.,(2015).After Decades of Death and Destruction, Shell Pays Just $\$ 83$ Million for Recent Oil Spills. GREENPAECE. Available at: http://www.greenpeace.org/usa/shell-oil-settlement-ogoniland/

BMZ, (2018). Adapting to climate change in the Lake Chad Basin. GIZ. Available at: https://www.giz. de/en/worldwide/24845.html

EDITOR, (2013). Policy lessons from the first Green Revolution program. BUSINESSDAY. Available at: https://www.businessdayonline.com/policy-lessons-from-the-first-green-revolution-programme/

ABL, (2015). Top 10 Highest Milk Producing Cattle Breeds in All Over the World. ABL Technology. Available at:https://abltechnology.wordpress.com/2015/06/12/top-10-highest-milk-producing-cattle-breeds-in-all-overthe-world/

Fameso T. F., (2013). Survey and Study on Timber Flows to Identify the Extent of Illegal Logging in Nigeria. ILLEGAL-LOGGING. Available at: https://www.illegal-logging.info/sites /files/chlogging/Tom\% 20

Fameso_Nigeria.pdf 
Okeke C. C., (2016). 'Nigeria's forest cover reduces at 3.5 percent yearly'. DailyTrust.com. Available at: https://www.dailytrust.com.ng/news/environment/-nigeria-s-forest-cover-reduces-at-3-5-percentyearly/150173.html

Knight M., (2010). Battling to preserve Nigeria's rainforest.CNN. available at: http://edition.cnn.com/2010/WORLD/africa/09/01/nigeria.rainforest.biodiveristy/index.htmlBOA, About us: BANK of AGRICULTURE, Available at: http://www.boanig.com/boa/about-us

Assemblyonline (2009). Nigeria's river basins and agricultural development. eWASH. Available at: http://assemblyonline.info/nigerias-river-basins-and-agricultural-development/

Ogwu L. C. A., (2008). POVERTY RELIEF: MORE PROGRAMS, MORE PAINS. NigeriaWorld. Available at: http://nigeriaworld.com/articles/2008/feb/083.html

Zhang, J. (2012). Delivering Environmentally Sustainable Economic Growth: The Case of China, Asia Society. Available at: http://asiasociety.org/files/pdf/Delivering_Environmentally_Sustainable_Economic_Growth_Case_C hina.pdf 